\title{
AZ INFORMÁCIÓGAZDÁLKODÁS KIHÍVÁSAI A GLOBÁLIS INFORMÁCIÓS GAZDASÁG KORÁBAN
}

Napjainkban már senki sem kérdőjelezi meg az információ- és a tudásmenedzsment alkalmazásának a gazdasági életben betöltött nélkülözhetetlen szerepét. Az is nyilvánvaló, hogy a mindehhez szervesen kapcsolódó globális információs gazdaság törvényei kivételes jelentőséggel bírnak a vezetéstudomány művelői számára. Jelen elméleti alapvetés több nemzetközi és hazai szakember, valamint a szerző információgazdaságról, információellátásról alkotott megállapításait tömöríti, kiindulópontul szolgálva a téma további, elmélyült tanulmányozásához.

„Az információ drága, de hülyének lenni sem olcsó.”

(Pázmándi Gyula)

Az európai integráció nyomán - ma még - szokatlan és némelykor kegyetlennek tûnő versenyhelyzetek napi részeseivé váltunk. Ennek fő mozgatórugója a fejlett országokra jellemző - globális gazdaság, ami a hagyományos kereteket szétfeszítve globális elektronikus gazdasággá (e-gazdaság), ${ }^{1}$ ún. új gazdasággá (New Economy) ${ }^{2}$ fejlődött; a társadalmi-technológiai változások hatására pedig a jövőkutatók (Masuda, Naisbitt) útjára indították a globális kor ${ }^{3}$ első lépcsőjeként az infokommunikáció robbanásszerű előretörését jellemző információs társadalom, majd az ezt túlhaladó, és a hasznosítható tudást középpontba helyező tudásalapú társadalom fogalmát és rendszerét. ${ }^{4,5}$ A kilencvenes évek közepén négy amerikai szerző (Esther Dyson, George Gilder, George Keyworth, Alvin Toffler) „kiáltványban" ${ }^{6}$ fogalmazta meg, hogy különbséget kell tennünk az információs sztráda és a kibertér (tudástér) között. Az információs- és tudástársadalom lényegi összehasonlítását az 1. táblázat magyarázza.

„Korunk tudósai az információs forradalmat kutatásaik során előzmények nélkül álló eseménynek fogják fel. Nem szabad azonban elfelejteni, hogy alig egy évszázada amerikai cégek egy másik hasonló forradalmi hullám részesei lehettek, ami átalakította az irodákat és az addigra hagyományos információkezelést is megváltoztatta"7 - vélekedik a cégeken belüli információáramlást vizsgálva JoAnne Yates. Valóban, ha végiggondoljuk, már a XIX. és a XX. század fordulóján elkezdődött az információs és kommunikációs technológiák (IKT) robbanásszerú átalakulása, mely napjainkban - a számítástechnika üzleti és közcélú adaptálása révén - többek között a vállalkozások és a civil szféra számára is egyaránt sürgető feladatként jelentkezik.

$\mathrm{Az}$,értelmes, jól informált társadalom” gondolatköre már a múlt század hatvanas éveiben napvilágot látott Robert Lane és Peter Drucker tollából, ${ }^{8}$ és olyan teoretikusoknak köszönhetően, mint Manuel Castells, folyamatosan tudományos munkák és vizsgálódások középpontjában áll. ${ }^{9}$ Pintér Róbert felhívja a figyelmet ${ }^{10}$ Castells - Pekka Himanennel közös - könyvében ${ }^{11}$ írt állítására, miszerint nem egyfajta információs társadalom modell létezik. Kifejtik annak számos módját, hogy egy társadalom eljusson az információs társadalomba. A szerzőpáros három markáns típust különböztet meg:

- szilícium modell (piacvezérelt, nyitott információs társadalom),

- szingapúri modell (autoriter, államilag vezérelt információs társadalom),

- finn modell (nyitott, jóléti információs társadalom). 
1. táblázat tudásipar (knowledge industry) -

Mi a különbség az információs és tudástársadalom között?

\begin{tabular}{|c|c|c|}
\hline $\begin{array}{l}\text { Összehasonlítási } \\
\text { szempont }\end{array}$ & Információs társadalom & Tudástársadalom \\
\hline Fókusz & Technológia központú & Tudásközpontú \\
\hline Hálózat/szolgáltatás & Infokommunikációs hálózatépítés & Tartalomszolgáltatás \\
\hline Demokráciamodell & $\begin{array}{l}\text { Változatlan (az ipari társadalmak } \\
\text { korának) demokrácia modellje }\end{array}$ & $\begin{array}{l}\text { Új típusú (hálózati) demokrácia } \\
\text { modell }\end{array}$ \\
\hline Társadalom & $\begin{array}{l}\text { Korlátozottan informált helyi } \\
\text { társadalom }\end{array}$ & Intelligens civil társadalom \\
\hline Társadalmi rétegek & Információgazdag elitrétegek & Információgazdag középrétegek is \\
\hline Stratégia & Elsősorban kontinentális stratégia & $\begin{array}{l}\text { Egyenrangú globális, nemzeti és } \\
\text { regionális stratégia }\end{array}$ \\
\hline Terjedés & Főként globális terjedés & Egyenrangú regionális terjedés \\
\hline Innováció & Technológiai innováció & Társadalmi innováció is \\
\hline Gazdaság & $\begin{array}{l}\text { Ipari-pénzpiaci és információs } \\
\text { gazdaság }\end{array}$ & Tudásalapú gazdaság \\
\hline Ipar & Technológiaipar & Társadalom „ipar” \\
\hline Állam, kormányzás & $\begin{array}{l}\text { Információkat is központosító } \\
\text { hatalomalapú kormányzás }\end{array}$ & $\begin{array}{l}\text { Tudásalapú fejlesztő, kreatív } \\
\text { állam }\end{array}$ \\
\hline Hozzáférés & $\begin{array}{l}\text { „Csak” a (fizikai) hozzáférés } \\
\text { lehetősége }\end{array}$ & $\begin{array}{l}\text { Tudatos hozzájutás és személyes } \\
\text { „tartalomszolgáltatás” }\end{array}$ \\
\hline Internet & $\begin{array}{l}\text { Szabályozatlan és kevesekhez eljutó } \\
\text { internet }\end{array}$ & $\begin{array}{l}\text { Részben, nem hagyományosan } \\
\text { szabályozott, a többség által } \\
\text { használt internet }\end{array}$ \\
\hline
\end{tabular}

Forrás: KISS Endre - VARGA Csaba: i. m., 2001, 192.p.

Ez némileg párhuzamba állítható Alexander Gerschenkron ipari korszakról alkotott írásával,12 amelyben az angol gazdaságtörténész ugyancsak három (ipari társadalmi) modellt ismertet:

- angol modell (vállalkozásközpontú),

- német modell (bank és pénzintézet központú),

- orosz modell (államilag vezérelt, központosított).

„A hetvenes évek közepének információs és könyvtártudományi szakzsargonjában az egyik leggyakrabban használt kifejezés az «információrobbanás» volt. Ma e kifejezéssel alig találkozni, viszont a nyugati szakirodalomban egyre-másra bukkannak fel azok a publikációk, amelyek a társadalmi-gazdasági fejlődés újabb fokáról és szakaszáról, az ún. információs gazdaságról - vagy tágabb értelemben információs társadalomról - szólnak."13 - kezdi 1986-ban megjelent tanulmányát Hegedûs Péter, és elemzi az információs gazdaság mibenlétét. ${ }^{14}$

Információ mint alapvető nemzeti erōforrás, s így közgazdasági kategória, információtranszfer (information transfer), információgazdaság (information economy), információgazdálkodás (information management), információs politika (information politics), ma rendkívül divatos és sűrün használt fogalmak, melyek Magyarországon az elsők között Rózsa György munkássága révén kerültek a tudományos körök figyelmének középpontjába. ${ }^{15} \mathrm{~A}$ nemzetközileg is elismert könyvtáros és közgazdász, a Magyar Tudományos Akadémia Könyvtárának (MTAK) nyugalmazott főigazgatója, részben már az 1960as években védett kandidátusi értekezésében, ${ }^{16}$ de teljes mértékben az 1987-ben készített akadémiai doktori disszertációjában, ${ }^{17}$ illetve annak 1988-ban kelt téziseiben ${ }^{18}$ foglalta össze információtudományi munkásságának eredményeit. „Az informatika alapkutatási, alkalmazási és müszaki oldalainak a második világháborúval kezdődött korszakos fejlődése azzal járt, hogy a priméren katonai, majd gazdaságipénzügyi-szervezési és ezeket követően a tudományos igények és szükségletek kielégítésére létrehozta az informatika világpiacát anyagban, ismeretben, emberben egyaránt. Végső soron ez a világpiac az alapja az «információs társadalom»-nak nevezett jelenségnek"19 - vallja Rózsa az információs társadalom keletkezéséről. Majd kifejti, hogy az elsőként Daniel Bell által részletesen tárgyalt ${ }^{20}$ posztindusztriális, majd információs társadalom lényege, hogy a szolgáltatási szektorra is kiterjeszti az információ fogalmát, illetőleg ennek átalakulását - utalva Gassmann munkájára ${ }^{21}$ - információs gazdaságként jelöli meg, mely tulajdonképpen a negyedik gazdasági szektor, ahol a foglalkoztatottak száma a leggyorsabban növekszik. $\mathrm{Az}$ információs társadalom legfejlettebb állapotát a tudásiparban látja Rózsa György, amelyet Machlup elsődleges információs szektor elmélete ${ }^{22}$ alapján információs eszközöket előállító ágazatra, oktatásra, kommunikációra, kutatásfejlesztésre $(\mathrm{K}+\mathrm{F})$ és információs szolgáltatásokra bont. Ez utóbbit - szűkebb megközelítés szerint - egyben információs gazdaságként is értelmezi. Rózsa szerint „minél nagyobb egy országban az áru jellegü információn ${ }^{3}$ mennyisége, forgalmazása és alkalmazása, annál fejlettebb a gazdaság. Vagyis összefüggés van a gazdasági fejlettség és az áru jellegű információ kereslete között."24 
Itt kell megemlíteni Marc Uri Porat ${ }^{25}$ munkásságát, aki - Fritz Machluppal ellentétben - a másodlagos információs szektor ${ }^{26}$ témakörében vizsgálta az információs gazdaságot. ${ }^{27}$

„Az információ az emberi lét kezdetéig nyúlik vissza. Sőt még azt sem mondhatjuk, hogy az emberi élőlény kizárólagos sajátossága"28 - írja Csikós-Nagy Béla, majd a közgazdaságtan, a globalizáció és az információ összefüggéseinek elemzésében kitér a XXI. század információs forradalmának kialakulására. ${ }^{29}$ Ennek részletes ismertetésére nincs módom, azonban kiemelem a neves közgazdász arra vonatkozó utalását, mely szerint az információ (közvetítés) és a gazdasági élet szoros összefüggése nem új keletű, de napjainkban fokozottan előtérbe kerül: „Tudjuk például, milyen fontos szerepet játszott a Nagy-Britannia által uralt világgazdaság működtetésében a tenger alatt lefektetett kábelrendszer, amely Londont Földünk legfontosabbnak tartott stratégiai pontjaival kötötte össze. Sok szó esett arról a szemaforos átviteltechnikáról is, amit a Reuters még a XVIII. században alkalmazott abból a célból, hogy mindenki mást megelőzően tudósíthasson a tőzsdehírekről, az árfolyamokról. A századforduló információs forradalmának lényege ettől minőségileg különbözik. A lényeget tekintve olyan elektronikus világháló megalkotását jelenti, ami a kommunikáció terén egyszerüen hatályon kívül helyezi a tér és az idő korlátait. Némi leegyszerüsítéssel úgy is fogalmazhatnánk: mindazok, akik be vannak kapcsolva ebbe a rendszerbe

- szobájukban készen kapják meg a világ bármely részén fellelhető információt, amire gazdasági döntéseikhez szükségük lehet,

- szobájukból létesíthetnek üzleti kapcsolatot pénzintézetekkel, kereskedelmi vállalatokkal stb."30

Az információs társadalom és a globális információs gazdaság természetesen nem jöhetett volna létre az internet térhódítása nélkül. ${ }^{31} \mathrm{Al}$ Gore alelnök által „szupersztrádának”, Quarterman nyomán pedig „a mátrix"-nak nevezett, ${ }^{32}$ egyenrangú csomópontokból álló számítógépek alkotta világháló mára mindennapjaink természetes részévé vált, mely a gazdasági életben is létfontosságú szerepet tölt be. Farkas János az internetnek és a globalizációnak a gazdasági szféra szereplőire gyakorolt hatásáról ekképpen vélekedik: „A szakirodalomban találkozhatunk azzal a hipotézissel, miszerint a globalizációs folyamat kifejlődésével a multinacionális társaságok egyre inkább nemzetközi hálózatokká alakulnak át. (...) Az információs technika potenciálját csak akkor lehet realizálni, ha koherens infrastruktúrát hoznak létre, ahol csak a rugalmas hálózat képes arra, hogy a különböző számítógépeken alapuló üzleti tevékenységeket összekapcsolja. A decentralizált gépeket a hálózat köti össze és teszi lehetővé újjászervezésüket. (...) Ez nem fantázia, hanem anyagi erő, mivel a háló fennállásának minden pillanatában informálja, támogatja a gazdasági döntéseket.”33

„A globalizáció, az új gazdaság és a tudásalapú társadalom makro- és mikroszinten egyaránt minőségileg új folyamațok során keresztül formálódik, valósul meg. (...) Az új jelenségek egyik fontos elemét az jelenti, hogy a termelés folyamata, termékei és szereplői alapvetően átalakulnak. A tulajdonképpeni termelés egyre inkább összeszereléssé (assembling) válik. Ezzel párhuzamosan a szűken vett termelés (termék-előállítás) súlya, tőke- és időigénye folyamatosan csökken az új termékek kifejlesztéséhez (kutatásfejlesztés, technologizálás, gyártásszervezés, logisztika stb.) és értékesítéséhez (reklám-marketing, értékesítés, garanciális és egyéb szolgáltatások stb.) képest. Míg a XX. század elején a felhasznált nyersanyag, energia stb. tette ki a termékek árának közel $90 \%$-át, addig a XX. század végére már az ismeretek és a szélesen értelmezett szolgáltatások érik el ezt az arányt. (Ezzel is értelmezhető az információs, majd a tudásalapú társadalom kialakulása a termelés szemszögéből vizsgálva.)"34 - olvasható Veress József kiváló dolgozatában. Ezt erősíti meg az Informatikai és Hírközlési Minisztérium (IHM) által készített $\mathrm{Az}$ Információs Társadalom Stratégiát (ITS) Előkészítő Tanulmány is: „A fejlett társadalmakban megfigyelheto” az a tendencia, hogy az ipari alapú gazdaságról áttérnek az információ alapú rendszerre, melyben egyre inkább a tudás lesz az alapvető erőforrás, az előállított termelési és fogyasztási termékekben, illetve szolgáltatásokban hozzáadott értékként egyre több lesz a tudás. A gazdaság tudásalapú gazdasággá, a társadalom tudásalapú társadalommá válik." 35

„A termelési tényezőket illetően tovább folytatódik a nyersanyag, az energia, a föld és a tőke szerepének a 70-es évek óta tapasztalt relatív leértékelődési folyamata, és növekszik a tudás, az ismeret jelentősége. A 2010-ig terjedő időszak az OECD-régióban a tudásbázisú gazdaság és társadalom kialakulásának extenzív szakasza lesz"36 - állapítja meg a tudás XXI. századi szerepéről Nyíri Lajos. A termékek tehát egyre kevesebb anyagot, s ezzel párhuzamosan egyre több információt foglalnak magukba. Az utóbbi hatalmas lehetőségeket rejt, hiszen korlátlanul reprodukálható, esetenként személyre szabható; az információs gazdaság hatásaként végképp megszunnt a határvonal a gyártás és a szolgáltatás között. 
Az elmúlt évtizedekben az OECD (Organisation for Economic Co-operation and Development $=\mathrm{Gaz}$ dasági Együttmúködési és Fejlesztési Szervezet) országokban az alacsonyabb technológiai színvonalat képviselő iparágak súlya mind a termelésben, mind a foglalkoztatásban folyamatosan csökkent. Ezzel szemben a tudásintenzív szektorok ellenkező tendenciát mutattak. „Míg korábban a fő kérdés a nyersanyagok, a kereskedelmi útvonalak feletti ellenőrzés biztosíthatósága és ezen keresztül a versenyelőny megszerzése volt, addig ma már egyre inkább a szellemi tulajdon birtoklása, speciális kompetenciák megszerzése, és az így előállított egyedi termékek globális terjesztési joga vezethet komparatív előnyökhöz a vállalatok, de nemzetgazdaságok szintjén is." 37

Az új gazdaságban az információ és a tudás megújuló erőforrásként, létünk főszereplőjévé lép elő, háttérbe szorítva a hagyományos javakat: „megfelelő tudás birtokában lehetővé válik az anyagok, szállítási eszközök, energia, munka és tőke helyettesítése, valamint idő és hely megtakarítása." $38 \mathrm{Az}$ információs (és tudás-) társadalom, illetve az új gazdaság kialakulása tehát elválaszthatatlan a társadalom és a gazdaság információigényének és ezáltal információellátásának óriási mértékű növekedésétől, az információgazdálkodás folyamatának és az információs gazdaságnak az előretörésétől, korszerü információpolitika (stratégia) - kormányok általi - megalkotásától, majd gyakorlati megvalósításától. A jövő a virtuális gazdaságé, hiszen a hálózatok a gazdasági szereplők számára kötelezővé teszik a globális üzletvitelt, ,a régi gazdaság vállalatai számára nincsen visszaút, az e-gazdaságba való bekapcsolódásnak nincs alternatívája."39

A modern vállalatirányítás az információk használatát a menedzsment természetes részének tekinti. ${ }^{40} \mathrm{Az}$ információ és annak beszerzésére szolgáló ráfordítás olyan vállalati befektetéssé válik, amely cselekvésre késztet, és ennél fogva profitot termel.

„A gazdasági növekedés 70-80\%-a mögött érhető tetten új és magasabb színvonalú tudás. A modern világban a hatalom, a presztízs és a jólét elsődleges forrásává vált a tudás." ${ }^{1}$

„A nagy és sikeres nemzetközi cégek most már nagyon is tisztában vannak a belső és külső információk pénzügyi értékével, s nagy összegeket fektetnek be az információs technikába és annak személyi erőforrásaiba hatékony használatuk érdekében." 42

„Az egyének és a szervezetek nap mint nap döntésekre kényszerülnek, és hogy ezek a döntések optimálisak legyenek, a döntéshozóknak a megfelelő időpontban kell hozzájutniuk a releváns információhoz."43
A tỏke és az információ szoros összefonódásának lehetünk tanúi, hiszen például információ nélkül senki sem ad hitelt. Megjelent az üzleti információ hiányából fakadó kockázat fogalma, az információhiány akár tragikus vállalati következményekkel járhat. ${ }^{44} \mathrm{Az}$ információ- és tudástranszfer nélkül felmerül a cost of not knowing (CONK), azaz a nem tudás költsége.

$\mathrm{Az}$ információrobbanás ${ }^{45}$ következtében rendelkezésre álló nagy tömegű információ használhatatlan és kezelhetetlen a gazdasági élet szereplői számára. Szelektálásra van szükség, melyet megfelelő szakmai és infrastrukturális háttér birtokában lehet csak elvégezni. Minél több a rendelkezésre álló információ, annál kevésbé hasznos - nyilván a felhasználó szemszögéből nézve, hiszen a redundáns elemek és a keresésre fordított, végül haszontalannak bizonyult idő miatt. A vállalatok tehát kizárólag releváns és adekvát információkat igényelnek. Cél, hogy a

- megfelelő információ,

- megfelelő felhasználónak,

- megfelelő időben,

- megfelelő formában,

- megfelelő minőségben,

- megfelelő áron,

- megfelelő helyen álljon rendelkezésre. ${ }^{46}$

A vállalatok életében igen nagy jelentőséggel bír az adat- és információbányászati, tudásfeltárási ${ }^{47}$ esetenként szövegelemzési tevékenység; ${ }^{48}$ az információs rendszerek, főképpen az adatbázisok (működésük lényegét az 1. ábra magyarázza) napi használata. Gondoljunk csak bele, hogy például nyilvános hozzáférésű online könyvtári katalógusoknál (OPAC $=$ Online Public Access Catalogue) vagy keresőmotoroknál (pl. Google) még a logikai operátorok (AND, OR, NOT) alkalmazása esetén is gyakran több száz, esetenként több ezer találatot kapunk, melyek nagy mennyiségüknél fogva kezelhetetlenek, s így használhatatlanok. Ennek következtében professzionális tartalomszolgáltatókra ${ }^{49}$ adatbányászokra, információkereső szakemberekre és intézményekre (intézményrendszerre) van szükség, akik megoldást nyújtanak, hiszen „napjaink problémája nem az, hogy a kívánt információ létezik, hanem az, hogy képesek vagyunk-e megtalálni és okosan használni." 50 Mindannyian tudjuk, hogy ,a gond manapság nem az információhoz való hozzájutás, hanem az információözön. Az információ szolgáltatója azzal termel valódi értéket, hogy megtalálja, megszűri és közvetíti azt, ami a fogyasztó számára hasznos."51 Az új típusú tájékoztató, információelemző és értékelő szakember - aki makro- és 
mikroszinten az információt szintetizált formában, személyre szabottan, ,átcsomagolva” nyújtja -, már Rózsa György akadémiai doktori értékezésében tudományos igényességgel felbukkan. Rózsa szerint a nyitott információgazdaság, az információtranszfer letéteményesei a könyvtárak és könyvtárosok mellett az információs ügynökségek és információs brókerek. A szerző tudományos információkra vonatkozó megállapításai az üzleti információkra is értelmezhetőek:

- Az átfogó ismeretszervezési ciklus egyik döntő hordozóját és szervezőjét olyan tudományos nagyüzemnek kell tekinteni, mint amilyen egy nagykönyvtár, illetve információs intézet.

- Ezt a sajátos nagyüzemet menedzselni kell, akárcsak egy nyereségorientált vállalkozást.

- Utóbbinál a nyereség közvetlenül mérhető, míg az információs nagyüzemnél a nyereség többnyire közvetetten, áttételesen jelentkezik kutatási termelékenység növekedés formájában.

- A közvetlen haszon inkább az információ felhasználójánál jelentkezik. 52

Az információs rendszerek működésének sematikus ábrázolása

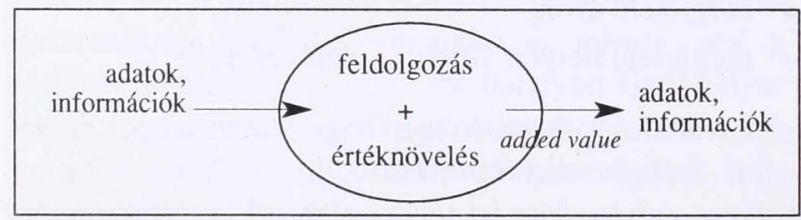

Forás: Kommenczy Bertalan: Információrobbanás - információszervezés - információkeresés. (Elektronikus prezentáció.) Eger, Eszterházi Károly Főiskola. 2002. A hozzáférés módja: www. ektf.hu/ kbert/infofeldolg2002.ppt (A letöltés ideje: 2002. 10.02.)

$\mathrm{Az}$ a folyamat, amelyben az adatból értelmezett, hasznosítható információ, majd a vezetői döntéshozatalt támogató vállalati tudás (,bölcsesség”) lesz (2. ábra), több közvetítő segítségével valósítható meg:

- A vállalkozó egyben információs szakember is, maga tájékozódik az ingyenes vagy előfizetéses adatbázisokból, személyes kapcsolatok útján. Mindez azonban sok időt elvesz munkájából, de kétség kívül költségtakarékos megoldás. Akkor működik jól, ha a gazdálkodó valóban jó adatbányász.

- Információs menedzser tartja kezében a vállalkozás információigényének kielégítését. Profi szakember, aki a cég alkalmazottjaként fő- vagy mellékállásban végzi e tevékenységét.

- Információbróker, azaz információs ügynököt bíz meg az ügyvezetés a vállalkozás információval való ellátására (outsourcing53). Mindenképpen meg- bízhatónak kell lennie, de még ekkor sem oszthatók meg vele stratégiai jelentőségű információk. ${ }^{54}$

- Információs nagyüzem, például könyvtár látja el információval a céget. Hazánkban ez a forma jelenleg még nem elterjedt, de remélhetőleg az európai uniós csatlakozás nyomán megfelelő színvonalú könyvtárak sokasága fog szolgáltatásokat nyújtani a vállalkozói kör számára. ${ }^{55}$

2. ábra

Adat - információ - tudás - bölcsesség

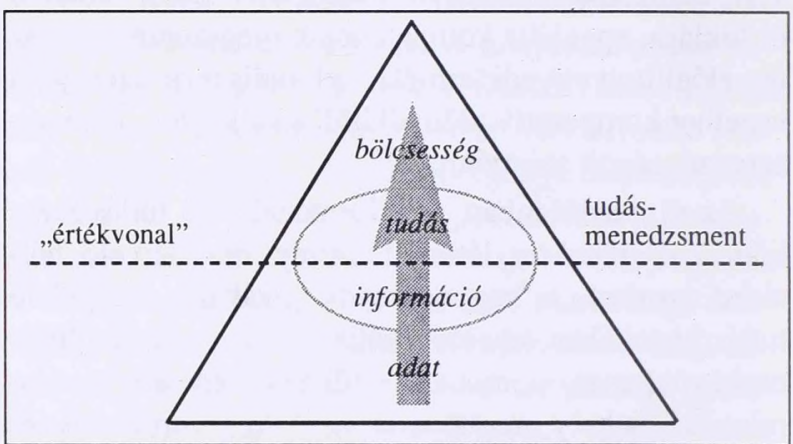

Forrás: Boda György: Információértékesítés és ,értékelés” az üzleti tanácsadásban. (Elốadás) MIBE konferencia. 2002. dec. 10. A hozzáférés módja: www:mibe.info (A letöltés ideje: 2002.12.15.)

$\mathrm{Az}$ egyes információközvetítők erősségeinek és gyengeségeinek összehasonlítását a 3. ábrán láthatjuk.

Összefoglalva tehát elmondható, hogy a vállalatok belső üzleti információs környezetének fejlesztésén, modernizációján túl - az Európai Unió célkitűzéseivel összhangban - a korszerű, gyors, megbízható, hálózatban hozzáférhető üzleti információ iránti kereslet kielégítése elengedhetetlen. A magyarországi vállalkozói információs rendszer, főképpen a gazdaság igényeinek megfelelő, széles kör számára hozzáférhető, kompatibilitást szem előtt tartó információs rendszerek (pl. hálózaton elérhető szakadatbázisok, később mesterséges intelligencia elvén alapuló szakértői rendszerek) és az ezekhez kapcsolódó komplex információs szolgáltatások kialakítása és működtetése ${ }^{56}$ hazánkban is elodázhatatlan feladattá vált. Elengedhetetlen a korszerü szakismerettel rendelkező információközvetítő szakemberek (információs menedzserek, informatikus könyvtárosok, információbrókerek, információs ügynökök) képzése és foglalkoztatása, ${ }^{57}$ az illetékes szervezetek koordinációs és finanszírozási közreműködése, az állam, a magánszektor, a civil-, illetve versenyszféra és a kutatás-fejlesztés, valamint a felsőoktatás világának kifinomult együttmúködése, az ún. PPP (public private partnership) kapcsolatok kialakítása.

Magyarország a globális folyamatoktól nem szigetelődhet el, akaratunktól függetlenül azok minket is 
Az egyes információközvetítők előnyös és hátrányos tulajdonságai

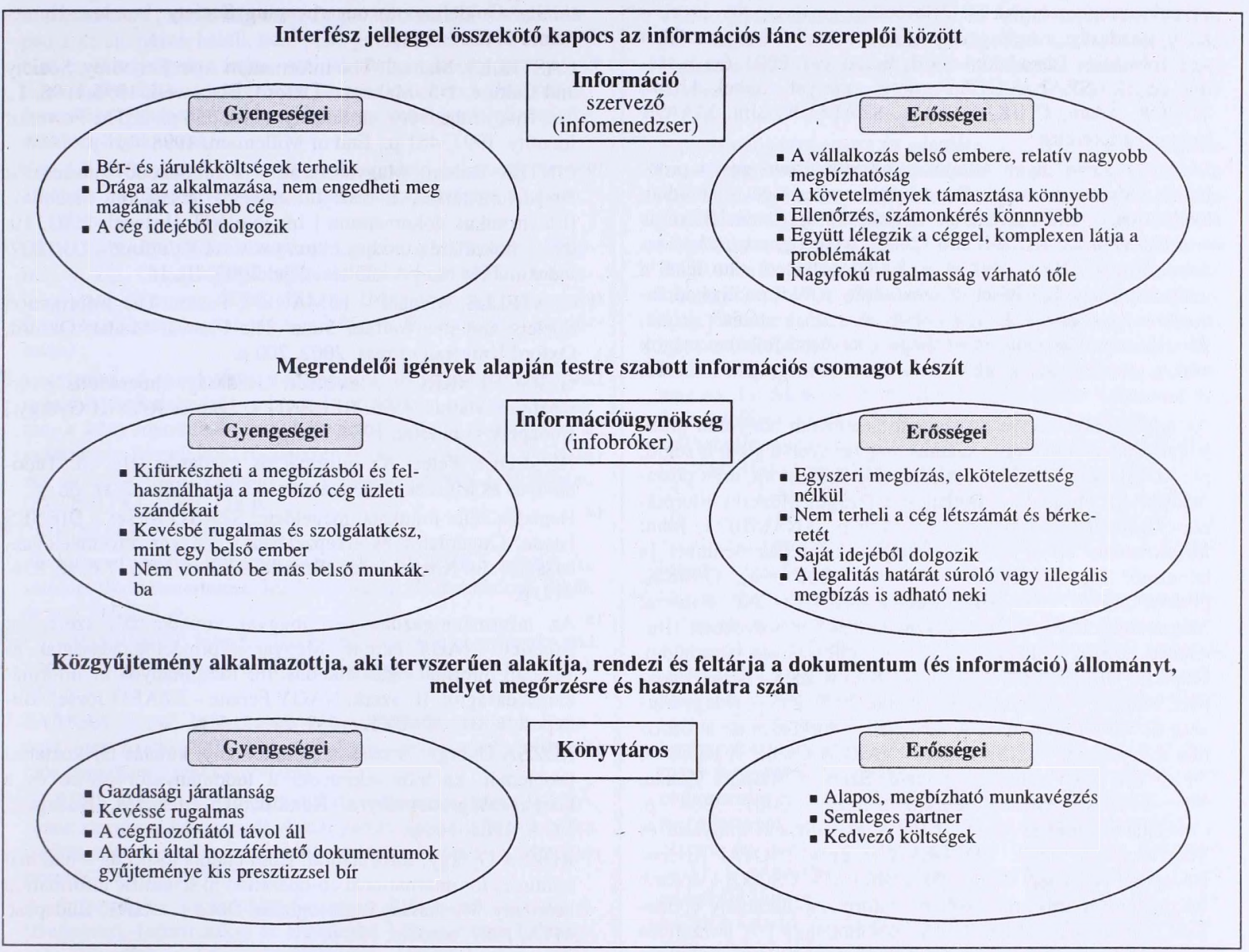

Forrás: Voit Pál, 2002, i.m. 177-178. p.

befolyásolnak, hiszen ,ha a globális világ jövője a tudástársadalom, akkor Magyarországon sem lehet más program, mint út az információs társadalomtól a tudástársadalomig." 58

Pintér Róbert és Z. Karvalics László megállapításai mindannyiunk számára egyértelműen megvilágítják a globális információs gazdaság mibenlétét: „az új gazdaság elsősorban információs, mert szereplőinek versenyképessége, így profitabilitása nagyban függ attól, hogy mennyire képesek a tudásalapú gazdaságban hatékonyan információt és tudást létrehozni, kezelni és

\section{Lábjegyzetek}

1 A hagyományos és új iparágak összevetését, a gazdaság egészének informatizálódását, technológiai megújulását, valamint a hagyományos szektorok „digitalizálásának” hatásait részletesen tárgyalja: SZABÓ Katalin (2002): Az információs technológiák szétterjedésének következményei a hagyományos szektorokban. In: Közgazdasági Szemle. 49. évf. 3. sz. p. 193-211. alkalmazni. Másrészt ez a gazdaság globális, mert a középpontjában álló termelési és fogyasztási tevékenységek, akárcsak a legfontosabb összetevők - úgy mint a tőke, munka, tiszta nyersanyagok, irányítás, információ, technológia, piac - globális szinten szerveződnek. Harmadrészt pedig ez a gazdaság egyszerre információs és globális, mert a termelés és a fogyasztás, illetve az annak hátterében álló verseny egy globális információs hálózatban folyik, amelynek létrejöttét az 1970-es évektől zajló információs technológiai forradalom tette lehetőve." 59

2 Az új gazdaság legfőbb jellemzője, hogy a szolgáltatások súlya mind a bruttó nemzeti termék (GDP) előálításában, mind a foglalkoztatottságot tekintve egyre nő; az informatika, a távközlés, a géntechnika, a robotika a globális gazdaság húzóágazatává válik; az internetalapú gazdaság, az elektronikus kereskedelem robbanásszerűen növekszik - összefoglalva: az információs- és a kommunikációs technológiák (IKT) válnak uralkodóvá az élet minden területén, így a gazdasági szférában is. A régi és az új iparágak között feszülő ellentét lassan kezd 
megszủnni, az új gazdaság már nem rendelhető hozzá egy meghatározott szektorhoz. A bányászattól a gépgyártáson keresztül az idegenforgalomig a legrégibb ágazatok körében is vezető szerephez jutnak az elektronikus gazdaság törvényei. Az új gazdaság, a tudásgazdaság tárgyalása köré szerveződött az Információs Társadalom c. folyóirat 3. évf. 2003. évi 1. száma (szerk. SZALAVETZ Andrea), melyet többek között TÖRÖK Ádám, CHIKÁN Attila, SZABÓ Katalin, MAJOR Iván neve fémjelez.

„A globalizáció olyan átfogó, mindenkit érintő egyes problémák tudománya, amelyek az egész emberiséget új módon, kvalitatívan, tendenciájukban egyenesen egzisztenciálisan is érintik." (Forrás: KISS Endre (2002): Megérteni a tudástársadalmat. In: eVilág. 2. évf. 8. p. 8.) Globalizáció alatt tehát a lokalitások egységesítését, összekötését, a földi civilizáció fokozatos egységesülését, így domináns státusz elérését értjük. Általánosan elfogadott nézet, hogy a kevésbé fejlett országok csak a globális gazdaságban erősödhetnek meg, ,,aki kimarad, az lemarad."

4 Az információs, illetve tudásalapú társadalom bonyolult problematikájának megértését számos magyar nyelvû kötet is segíti, pl.: MASUDA, Yoneji: Az információs társadalom, mint posztindusztriális társadalom. Budapest, Országos Műszaki Információs Központ és Könyvtár. 1988. 156 p. - NAISBITT, John: Megatrendek. Tíz új irányzat, amelyek átalakítják életünket. [a bevezetőt írta MAROSÁN György.] [Budapest], OMIKK. [1987.] 245 p. - NAISBITT, John - ABURDENE, Patricia: Megatrendek 2000. Tíz új irányzat a kilencvenes években. [Budapest], OMIKK. 1991. 350 p. - Az információs társadalom Összeáll. DEMETROVICS János - KEVICZKY László. Budapest, Magyar Tudományos Akadémia. 2000. 235 p. (Magyarország az ezredfordulón. 6. A közlekedés, hírközlés az informatika fejlesztése). - KISS Endre - VARGA Csaba: A legutolsó utolsó esély. Új valóság, új vízió. Szerk. CSÖRGŐ Zoltán. Nagy-kovácsi, Stratégiakutató Intézet. 2001. 384 p. (Tudástársadalom könyvek, 1.) - A globalizáció kihívásai és Magyarország. Szerk. FÖLDES György - INOTAI András. Budapest, Napvilág Kiadó. 2001. 400 p. - CSORBA József: Információ az információról. Az információtudomány építkezése. Témavázlat. [Elektronikus dokumentum.] A hozzáférés módja: http://www.inco.hu/inco3/infopol/cikk3.htm. A letöltés ideje: 2002. 10. 20. - Az információs társadalom kérdéskörének gyakorlati megközelítésével közérthetően foglalkozik és számos gyakorlati tanáccsal szolgál: SEBESTYÉN György: Légy az információs társadalom polgára! Budapest, ELTE Eötvös Kiadó. cop. 2002. 366 p.

Érdemes tisztázni az adat, információ és a tudás fogalmát. Adat alatt értjük az eseményekkel kapcsolatos objektív tények összességét. Az információ olyan adat, amely változást idéz elő, befolyásolja a címzettet, újdonságtartalma van, tehát informál. A tudás tapasztalatok, értékek és kontextuális (összekapcsolt) információk heterogén és folyton változó keveréke, egyes megközelítések szerint szakértelem, bölcsesség, melynek kulcsszerepe van a döntések meghozatalában. (Forrás: DAVENPORT, Thomas H. - PRUSAK, Laurence: Tudásmenedzsment. [Ford. ANDÓ Éva]. Budapest, Kossuth Kiadó. 2001. p. 17-22. (VIP 1419-3000))

6 DYSON, Esther - GILDER, George - Keyworth, George TOFFLER, Alvin: A ,kibertér” és az ,amerikai álom.” Magna Charta a Tudás Korához. 1.2 verzió. 1994. augusztus 22. Ford. DRÓTOS László. In: Replika. 8. évf. 1997. 26. sz. 149-163. p.

7 YATES, JoAnne: A cégeken belüli információáramlás alakulása 1850 és 1920 között. Ideológia, információtechnikák és információtechnológiák. Ford. BATTYÁN Katalin. In: Információs Társadalom. 2. évf. 2002. 3. sz. 57.p.
8 LANE, Robert: The Decline of Politics and Ideology in Knowledgeable Society. In: American Sociological Review. 31. évf. 1966. 649-662. p. - DRUCKER, Peter: The Age of Discontinuity. Guidelines to our changing Society. London, Heinemann. 1969. 369 p.

9 CASTELLS, Manuel: The Information Age: Economy, Society and Culture. 1-3. Malden - Oxford, Blackwell. 1996-1998. 1., The Rise of the Network Society. 1996. 556 p.; 2. The Power of Identity. 1997. 461 p.; End of Millenium. 1998. 441 p.

10 PINTÉR Róbert: Magyarország - a rejtőzködő információs társadalom tézise. 2. rész: Információs társadalom modellek. [Elektronikus dokumentum.] In: INFINIT Hírlevél. 2003. 10. 09. A hozzáférés módja: http://www.ittk.hu/infinit/2003/1009/ indexmuhely.html A letöltés ideje: 2003. 10.16.

11 CASTELLS, Manuel - HIMANEN, Pekka: The Information Society and the Welfare State. The Finnish Model. Oxford, Oxford University Press. 2002. 200 p.

12 GERSCHENKRON, Alexander: Gazdasági elmaradottság történelmi távlatból. [Vál. BEREND T. Iván és RÁNKI György.] Budapest, Gondolat. 1984. 551 p.

13 HEGEDÜS Péter: Az információs gazdaság felé. In: Tudományos és Műszaki Tájékoztatás. 33. évf. 1986. 2. sz. 68. p.

14 Hegedűs Péter munkáját megelőzte: SZABÓ József - DIENES István: Gondolatok és elképzelések a magyar információgazdaságról. In: Közgazdasági Szemle. 33. évf. 1985. 7-8. sz. 856872. p.

$15 \mathrm{Az}$ információgazdaságtan magyar vonatkozású szereplőit ismerteti: NAGY Ferenc: Magyar információgazdaságtan és vállalati információgazdálkodás. In: Tanulmányok az információgazdaságról. II. Szerk. NAGY Ferenc - SZABÓ József. Budapest, KSH - OMIKK. 1989. 203-215. p.

16 RÓZSA György: A társadalomtudományi kutatás tájékoztatási problémái, különös tekintettel a tudományszervezésre és a közgazdaságtudományra. Kandidátusi értekezés. Budapest, MTA. 1963. 166 p.

17 RÓZSA György: Information: from claims to needs - national aptitudes for international co-operation in scientific information economy. Munkásság összefoglalás. Doktori tézisek. Budapest, MTA. 1987. október. 195 p.

18 RÓZSA György: Információ: az igényektôl a szükségletekig nemzeti adottságok és nemzetközi együttműködés a tudományos információgazdálkodásban. Doktori tézisek munkásság összefoglalásához. Budapest, MTA. 1988. február. 23 p.

19 Uo. 1.p.

$20 \mathrm{Az}$ posztindusztriális, illetve információs társadalom (postindustrial, information society) kifejezést Daniel Bell amerikai szociológus használta elôször. Ld. BELL, Daniel: The coming of post-industrial society. A venture in social forecasting. New York, Basic Book. 1973. 507 p.

21 GASSMANN, H.: Is there a fourth economic sector? In: The OECD Observer. 1981. 113. sz. 18-20. p.

22 Machlup definiálta elsőként az ismeretek előállítását és terjesztését végzô szektor fogalmát (knowledge industries), és állapította meg részarányát az Amerikai Egyesült Államokra vonatkozóan. Ld. MACHLUP, Fritz: The production and distribution of knowledge in the United States. Princeton, Princeton University Press. 1962. 416 p.

23 Rózsa György az információt két fổ típusra bontja. Megkülönbözteti az áru jellegű (termelőszféra) és a szolgáltatás jellegû (művelődés, ismeretterjesztés) információt.

24 RÓZSA György, 1988.: i. m. 5. p.

25 PORAT, Marc Uri: The information economy. Definition and measurement. Washington, U.S. Department of Commerce, 
Office of Telecommunications. 1977. 250 p. (OT Special publication. 77-12/1/)

26 Elsődleges információs szektor alatt az információs javak és szolgáltatások piacát, míg másodlagos információs szektor alatt pedig az ún. házon belüli, nem piaci jellegû́ hozzáadott értékkel bíró tevékenységeket értjük, melyek nem az információs javak és szolgáltatások termelésében játszanak szerepet. Amikor információs gazdaságról beszélünk, az elsődleges információs szektort értjük alatta.

27 Vö.: SZABÓ József: Tévhitek az információ gazdasági természetérôl. In: Tanulmányok az információgazdaságról. II. (i. m.) 23-24. p.

28 CSIKÓS-NAGY Béla: Közgazdaságtan a globalizáció világában. 2. köt. Gazdasági globalizáció. Budapest, MTA Társadalomkutató Központ. 2002. 291. p. (Magyarország az ezredfordulón. Stratégiai kutatások a Magyar Tudományos Akadémián)

${ }^{29} \mathrm{Az}$ információ elméletéről, információs folyamatokról, az információ öt forradalmáról (a beszéd forradalma, az írás forradalma, a könyvnyomtatás forradalma, a távközlés forradalma, a számítógép forradalma) részletesen olvashatunk: FÜLÖP Géza: $\mathrm{Az}$ információ. [Egyetemi és főiskolai jegyzet.] Budapest, [ELTE BTK]. 1996. 178 p.

30 CSIKÓS-NAGY Béla, 2002.: i. m. 292. p.

$31 \mathrm{Az}$ internet történetéről áttekintést ad: KEVICZKY László: Az internet rövid ismertetése. In: Az információs társadalom, 2000. (i. m.) 211-229. p.

32 QUARTERMAN, John S.: The Matrix. Computer networks and conferencing systems worldwide. Bedford, Digital Press. 1990. $719 \mathrm{p}$.

33 FARKAS János: Információs- vagy tudástársadalom? Budapest, Aula Kiadó. 2002. 108. p. (Infonia szakkönyvek. Információs társadalom szakkönyvtára)

34 VERESS József: A magyar vállalati-vállalkozói szféra fejlődésének stratégiai kérdéseirôl. A magyarországi vállalkozói szféra (mikroszféra) jövője. In: A globalizáció kihívásai és Magyarország, 2001. (i. m.) 291. p.

35 Az Információs Társadalom Stratégiát Előkészítő Tanulmány. [Budapest], Informatikai és Hírközlési Minisztérium Információs Társadalom Stratégia Helyettes Államtitkárság. 2002. október 18. 5. p.

36 NYÍRI Lajos: A tudás szerepe az új társadalomban. In: A globalizáció kihívásai és Magyarország, 2001. (i. m.) 183. p.

37 Uo. 159-162. p.

38 TOFFLER Alvin - TOFFLER Heidi: Creating a new civilization. The politics of the new third wave. Atlanta, Turner Publishing, Inc. 1995. 35. p. [Ism. VERESS, 2001.: i. m. 292. p.]

39 SZABÓ Katalin, 2002.: i. m. 210. p.

40 ITS, 2002. (i. m.) 73. p.

41 Knowledge and Learning. Towards a Learning Europe. Futures Report Series 14. Joint Research Centre of the European Union. IPTS (Institute for Prospective Technological Studies). 1995 December [Ism. NYÍRI Lajos, 2001.: i. m, 159. p.]

42 LOWE, M.: A vállalkozási információk kora. In: Tudományos és Mûszaki Tájékoztatás. 40. évf. 1993. 7. sz. 280. p.

43 HUSZÁR Ernőné: A közgazdasági szakirodalmi információs rendszer felé. In: Tudományos és Műszaki Tájékoztatás. 38. évf. 1991. 9-10. sz. 383. p.

44 BARTERS, J. C.: Bank- és céginformációk beszerzésének lehetôségei az érintett térségben. In: Magyar tőkebefektetések külföldön. V. Pénzpiac konferencia. Szerk. KOVÁCS Dénes. Budapest, CMC Rt. 1994. 69-73. p.
$45 \mathrm{Az}$ információrobbanás kifejezés mögött az információ tömegének megduplázódása áll, melyet egyes szakértők évenkénti periódusra határoznak meg.

46 Vö.: Logisztikában alkalmazott „7M” modell, pl. VARGA Sándor - BEDő Gyula - LőRINCZI Gyula: Vállalkozások gazdaságtana a mérlegképes könyvelố vállalkozási szakos hallgatók részére. Szerk. VARGA Sándor. Budapest, Perfekt Kiadó. 1997. 175. p.

47 A tudásmenedzsment és az adatbányászat témakörével kapcsolatosan számos kiadványt jelentettek meg, illetve több konferenciát is rendeztek az utóbbi időben, pl. Adatbányászat és tudásfeltárás. Újszerû eszközök és technikák az üzleti döntéstámogatáshoz. Budapest, Hilton Budapest Westend. 2003. január 28-29. Institute for International Research. (http://www.iirhungary.com). - A tudásmenedzsmenttől a versenytársfigyelésig. Budapest, Benedict School. 2001. december 15. Magyar Információbrókerek Egyesülete (http://www.mibe.info). - KÁDÁR Edit: Az adatbányászat eredményei és azok üzleti alkalmazása. In: Menedzsmentfórum. [Elektronikus dokumentum.] A hozzáférés módja: http://www.menedzsmentforum.hu/cikkek/tanulmany.php?ter $=4 \&$ article $=1669 \&$ page $=1 \&$ PHPSESSI $\mathrm{D}=248 \mathrm{fe} 3 \mathrm{f} 8853$ cee0e01ea2b23b477c56c A letöltés ideje: 2003. 03. 10. - DAVENPORT, Thomas H. - PRUSAK Laurence, 2001: i. m. 196 p. - ADRIAANS, Pieter - ZANTINGE, Dolf: Adatbányászat. [Budapest], Panem Kiadó. 2002. 157 p. (Panem információtechnológia.)

47 Napjainkban fokozottan előtérbe kerül a szövegbányászat, azaz szövegek előre beállított paraméterek alapján történő gyors, automatikus (számítógéppel végzett, szoftver által vezérelt) szelektálása, értelmezése, mely nemcsak a kulcsszavak alapján, hanem a szöveg mondanivalója, az egyes mondatok mögötti szemantikai tartalmak, relációk, logikai összefüggések figyelembe vételével is lehetséges. (Léteznek az élő beszédet felismerő programok is, melyek alkalmazása az ún. dialógusmenedzsmentre épül.): ASZALÓS Péter: Szövegbányászat. Tudásmenedzsment szoftvertechnológiák az üzleti információszerzésben és konkurenciaelemzésben. [Elektronikus dokumentum.] A hozzáférés módja: http://www.gmconsulting.hu/inf/ cikkek/185/index.htm A letöltés ideje: 2003. 10. 15. - GALUSKA László Pál: Gondolatvadászat; rejtett információk írott szövegekben. [Eletkronikus dokumentum.] A hozzáférés módja: http://www.gmconsulting.hu/inf/cikkek/183/index.htm A letöltés ideje: 2003. 10. 15. - MIKULÁS Gábor: Rejtjelfejtők. Szövegelemzés az üzleti életben. In: Figyelő. 47. évf. 2003. 51. sz. 52-53. p.

48 ITS, 2002. (i. m.) 73. p.

${ }^{49} \mathrm{~A}$ multinacionális tartalomszolgáltató vállalkozások közül kiemelkedik a Dialog Corporation (http://www.dialog.com), amely Dialog, DataStar és Profound rendszerében, parancs- és menümódban, egységes lekérdezési, rendezési és megjelenítési platformon megközelítően ezer adatbázis egymilliárd rekordjához biztosít hozzáférést szinte minden témakörből az egész világon. Ezzel a Dialog Corporation a világ harmadik legnagyobb információvagyonát kínálja, e tekintetben a CIA és a Microsoft elốzi csak meg. A Dialog online szolgáltatóközpont (host) által biztosított adatbázisok többsége szekunder (szurrogátum) szintű, egyre szélesebb köre azonban már primer (teljes szövegű) dokumentumokat tartalmaz. Ezzel a Dialog a Dokumentumok egyetemes számbavételének $(\mathrm{UBC}=$ Universal Bibliographic Control) programja mellett a Publikációk egyetemes hozzáférhetőségét (UAP = Universal Availability of Publications) célzó világméretû kezdeményezés élharcosának is tekinthetô.

50 [MAGYAR Gábor demonstrációja.] In: KISS Endre - VARGA Csaba, 2001.: i. m. 359. p. 
51 SHAPIRO, Carl - VARIAN, Hal R.: Az információ uralma. A digitális világ gazdaságtana. [Ford. SZIKINGER Péter]. Budapest, Geomédia Kiadói Rt. 2000. 16-17. p. (Geomédia szakkönyvek. Üzlet és menedzsment.)

52 RÓZSA György, 1988.: i. m.: 5. p.

53 Az outsourcing (tevékenység-kihelyezés, kiszervezés vagy kiszerveződés) szűk értelemben valamely - korábban a vállalaton belül végezett - tevékenység külső szolgáltatóra bízását jelenti. A kifejezés eredeti jelentése (outside resource using) külső erőforrások felhasználása, külső szolgáltató igénybevétele. Tágabb értelemben korábban esetleg nem igényelt tevékenység esetében is használatos. A kihelyezéstôl leginkább költségcsökkentést várnak. A külső szolgáltató a méretgazdaságosság, illetve a nagyobb tapasztalat révén kisebb költséggel múködhet, az igénybevevőnek pedig nem kell fejlesztésre, beruházásra költenie. A költségelổnyökön túl fontos, hogy a vállalat az úgynevezett alapvető, lényegi képességeire koncentrálhat, amelyek terén versenyelônyt érhet el.

54 Vö.: Az információbróker tevékenység európai szabályzata. Európai Információkutatók Hálózata (European Information Research Network = EIRENE). [A Magyar Információbrókerek Egyesülete (MIBE) kézirata.] $3 \mathrm{p}$.

55 Vö.: VOIT Pál: A szervezett információgazdálkodás szerepe a kis- és középvállalkozások működésében. In: „A struktúraváltás évtizede" 1992-2002. Jubileumi tudományos konferencia (JTK'2002). 2002. szeptember 9-10. Tatabánya, Modern Üzleti Tudományok Főiskolája. 2002. 176-177. p. - MIKULÁS Gábor: Pióca, dögkeselyű vagy csak egyszerủen infobróker? In: Könyv, Könyvtár, Könyvtáros. 10. évf. 2001. 9. sz. 19-27. p. -
MIKULÁS Gábor: Az információ- és tudáspiac új szereplője, az információbróker. In: Marketing \& Menedzsment. 37. évf. 2003. 1. sz. 17-24. p.

56 Vö.: DOBAY Péter: Vállalati információmenedzsment. Egyetemi tankönyv. Budapest, Nemzeti Tankönyvkiadó. 1997. 290 p. - Tudományos és Müszaki Tájékoztatás 40. évf. 1993. 6. sz. [Te-matikus különszám.]

57 Vö.: MIKULÁS Gábor: Az információ- és tudáspiac új szereplôjje, az információbróker. In: Marketing \& Menedzsment. 37. évf. 2003. 1. sz. 17-24. p. - VOIT Pál: A szervezett információgazdálkodás șzerepe a kis- és középvállalkozások mûködtetésében. In: „A struktúraváltás évtizede” 1992-2002. Jubileumi tudományos konferencia (JTK'2002). 2002. szeptember 9-10. Tatabánya, Modern Üzleti Tudományok Fôiskolája. 2002. 172182. p. - KISZL Péter: Hogyan tovább? Üzleti információszolgáltatás a magyarországi könyvtárakban. In: Tudományos és Mûszzaki Tájékoztatás. 51. évf. 2004. 9. sz. 371-378. p. - KISZL Péter: Business - informatikus könyvtáros hallgatóknak. A vállalkozói, üzleti információ oktatása a felsőfokú könyvtárosképzésben. In: Tudományos és Mũszaki Tájékoztatás. 51. évf. 2004. 11. sz. 484-494. p. - Üzleti információ projekt az ELTE BTK könyvtártudományi tanszékén [Honlap.] http:// harleqin.elte.hu/businessinfo

58 VARGA Csaba: Tudástársadalom és tudásrégió. In: KISS Endre - VARGA Csaba, 2001.: i. m. 179. p.

59 PINTÉR Róbert - Z. KARVALICS László: Információ és globalizáció. Az infrastruktúrától a társadalomig. In: A globalizáció kihívásai és Magyarország, 2001. (i. m.) 206. p. 